\title{
Old Wine in a New Bottle-Focus on Candidial Vaccine
}

\author{
Prabhusaran $\mathrm{N}^{1 *}$, Ganeshkumar $\mathrm{A}^{1,2}$, Pramila $\mathbf{M}^{1,3}$, Revathi $\mathbf{R}^{4}$ and Rajaram $\mathbf{R}^{2}$ \\ ${ }^{1}$ Department of Microbiology, Trichy SRM Medical College Hospital and Research Centre, India \\ ${ }^{2}$ Department of Marine Sciences, Bharathidasan University, India \\ ${ }^{3}$ Department of Biotechnology, Nehru Memorial College, India
}

${ }^{4}$ Department of Obstetrics \& Gynaecology, Trichy SRM Medical College Hospital and Research Centre, India

*Corresponding author: Prabhusaran N, Department of Microbiology, Trichy SRM Medical College Hospital and Research Centre, India

Submission: 㘹 March 28, 2018; Published: 眥 April 27, 2018

\begin{abstract}
Vaginal Candidacies or vaginal candidial infection is one of the most common infections in reproductive age and older age woman. It is usually managed by first line treatment of azoles and other antifungal antibiotics through oral, tropical and intra-vaginal preparations. Followed by if recurrence observed, intravenous preparation also administrated. During the past decades, the incidence of vaginal candidiasis and recurrent vaginal Candidiasis was frequently occurred due to poor/ mis-diagnosis, development of drug resistance, infection by non albicans species, phenotypic and genetic adaptation towards the drug Candidate. Even though, there are enormous new antifungal antibiotics was introduced but the incidence of drug resistance was more concern. So in order to overcome this circumstance the researchers are tend to make a new Candida to prevent the Candida infection. In this review we are trying to achieve the importance Candida vaccine thus should provide a better option for candidiasis.
\end{abstract}

\section{Vaginal Architecture and Candidiasis}

Vaginal stratified squamous epithelial cells are the outer most self defence agent against several infectious agents [1]. It was procured the host immune system acted as barrier against sexually transmitted diseases to opportunistic infections. Vagina showing unique micro environment which facilitates the attachment of probiotic organism like Lactobacillus [2]. Because of the loosely bounded cells with enriched glycogen afford to cross the endogenous organisms around the layer [3]. However, due to the production of several antimicrobial peptide and other immune molecules primarily protects the vaginal environment [4]. In most cases, a simple columnar epithelium of endocervix is the major site of infection. During the course of normal phase Candida living like a commensal organism, but when it becomes uncontrolled growth possible to be a pathogenic organism. Formally Candida albicans alone consider as a causative agent of RVVC (Recurrent vulvovaginal candidiasis), but the detailed investigations evidenced the uncommon non albicans species to be the part of the chronicity of the infections $[5,6]$.

Risk Factors of Recurrent Vulvovaginal Candidiasis (RVVC)

Candida albicans and non albicans species are present in lower reproductive tract of healthy women with asymptomatic manner.
The potential risks of vaginal candidiasis are majorly associated with excessive carbohydrate source such as uncontrolled diabetes, hormonal therapy leading to formation of glycogen. Followed by disturbance of vaginal epithelial architecture by vaginal douching, improper usages of vaginal lubricants, frequent sexual intercourse and sexual mediated transformation [7,8]. Most importantly, recurrent and un-prescribed usage of antibiotics, immunesuppressive agents reduces the lactobacilli count which overlooked to regulate the Candida homeostasis leading to candidial overgrowth [9].

\section{Virulence Factors of RVVC}

Candida species produces wide range of virulence factors that includes production of adhesion molecules (Als1p, Als5p) [10], secretion of several classes of proteolytic enzymes (secreted aspartyl-proteinase (Sap 1 to 10) [11,12], heat shock protein, biofilm formation, drug resistance, germ tube formation (Hwp1p, hyphal- and germ tube-specific gene $[13,14]$ and morphological transition. Candida cells were grown like oval in shape, in some condition the yeast form was transited in to hyphae form. This form of Candida was more pathogenic than the yeast form; also it was linked with other virulence factors like Sap and Als proteins [15]. During the infection, the adhesion molecules initiates the adhesion of candidial cells to the host epithelial cells, vigorous proliferation 
takes place leads to abnormal and obnoxious growth due to the expression of Hwp1 protein $[3,10]$.

\section{Therapeutic Failure of RVVC}

Till 19th century, several antifungal antibiotics were introduced for candidial prophylaxis and their broader classifications of antifungal are azoles, polyenes, echinocandins, allylamines and pyrimidines. These target the candidial cell wall and cell membrane, DNA/ RNA synthesis and arrest the function microtubules [16] In the past two decades, the incidence of RVVC were enormously increased because of increased and unrestricted usages of azoles [17] and other antifungal antibiotics, rises the incident of disease prevalence through development of drug resistant to C. albicans and other non albicans species [18]. In some cases, a group of chaperones reported from $\mathrm{C}$. albicans showing reduced accessibility of drug Candidate. Among them Hsp90 regulates drug resistance, morphogenesis, bio-film formation and virulence [15].

\section{Development of New Strategies for Candida Vaccination}

The family of Sap proteins are the major concern of vaginal candidiasis and RVVC, because of increased invasion through the disturbance of vaginal architecture. Among them Sap 1, 2 and 3 having the antigenic interaction with better immune response against $\mathrm{C}$. albicans and non albicans species $[12,19]$. The excellent immunogenicity modulation of Sap protein family was determined as one among the important factor of developing anti-candidial vaccine. From the last decade, enormous studies highlighted the importance of candidial vaccine in order to prevent the pathogenicity and virulence of the RVVC. The detailed investigations of two different vaccines against C. albicans are

$$
\text { a. Protein that belonging to } \operatorname{Sap}(\operatorname{Sap} 2) \text { family }[20,21] \text { and }
$$

b. Als (Als 9) proteins have been completed phase I trials and approved for RVVC treatment.

Recently, the data demonstrated the importance of Sap 2 against mucosal infections of $\mathrm{C}$. albicans with some formulation by virosomes in order to develop better vaccine for candidiasis [21].

\section{Conclusion}

Vaccination is one of the best methods of elimination of pathogenesis of several infectious diseases. But in the account of candidiasis, our own immune system recognised Candida as commensal organism, so it falls to develop immunogenicity towards the candidial infection. Also there are several controversies were raised against candidial vaccine, because of lower specificity, higher cost and others. However, detailed investigations by the expertise peoples will be the option to eradicate the controversies over the candidial vaccination.

\section{References}

1. Reis Machado J, Da Silva MV, Cavellani CL, Dos Reis MA, Monteiro ML, et al. (2014) Mucosal immunity in the female genital tract, HIV/AIDS. BioMed Res Int 2014: 350195.
2. Martin R, Soberon N, Vazquez F, Suarez JE (2008) Vaginal microbiota: composition, protective role, associated pathologies, and therapeutic perspectives. Enferm Infecc Microbiol Clin 26(3): 160-167.

3. Naglik JR, Moyes DL, Wachtler B, Hube B (2011) Candida albicans interactions with epithelial cells and mucosal immunity. Microbes Infect 13(12-13): 963-976.

4. Yarbrough VL, Winkle S, Herbst Kralovetz MM (2015) Antimicrobial peptides in the female reproductive tract: a critical component of the mucosal immune barrier with physiological and clinical implications. Hum Reprod Update 21(3): 353-377.

5. Kennedy MA, Sobel JD (2010) Vulvovaginal candidiasis caused by non albicans Candida species: new insights. Curr Infect Dis Rep 12(6): 465470 .

6. Sobel JD (2002) Pathogenesis of recurrent vulvovaginal candidiasis. Curr Infect Dis Rep 4(6): 514-519.

7. Reed BD, Zazove P, Pierson CL, Gorenflo DW, Horrocks I (2003) Candida transmission and sexual behaviours as risks for a repeat episode of Candida vulvovaginitis. J Womens Health 12(10): 979-989.

8. Oriel ID, Partridge BM, Denny MI, Coleman JC (1972) Genital yeast infections. BMJ 4(5843):761-764.

9. Cuervo G, Garcia Vidal C, Puig Asensio M, Vena A, Meije Y, et al (2017) Echinocandins Compared to Fluconazole for Candidemia of a Urinary Tract Source: A Propensity Score Analysis. Clin Infect Dis 64(10): 13741379.

10. Calderone RA, Fonzi WA (2001) Virulence factors of Candida albicans. Trends Microbiol 9(7): 327-335.

11. De Bernardis F, Arancia S, Morelli L, Hube B, Sanglard D, et al. (1999) Evidence that members of the secretory aspartyl proteinases gene family (Sap), in particular Sap2, are virulence factors for Candida vaginitis. J Infect Dis 179(1): 201-208.

12. Schaller M, Borelli C, Korting HC, Hube B (2005) Hydrolytic enzymes as virulence factors of Candida albicans. Mycoses 48(6): 365-377.

13. Sundstrom P (1999) Adhesins in Candida albicans. Curr Opin Microbiol 2(4): 353-357.

14. Staab JF, Ferrer CA, Sundstrom P (1996) Developmental expression of a tandemly repeated, proline and glutamine-rich amino acid motif on hyphal surfaces on Candida albicans. J Biol Chem 271(11): 6298-6305.

15. Mayer FL, Wilson D, Hube B (2013) Candida albicans pathogenicity mechanisms. Virulence 4(2): 119-128.

16. Campoy S, Adrio JL (2016) Antifungals. Biochem Pharmacol 133: 86-96.

17. Marchaim D, Lemanek L, Bheemreddy S, Kaye KS, Sobel JD (2012) Fluconazole resistant Candida albicans vulvovaginitis. Obstet Gynecol 120(6): 1407-1414.

18. Sobel JD (2006) Management of recurrent vulvovaginal candidiasis: Unresolved issues. Curr Infect Dis Rep 8(6): 481-486.

19. Pericolini E, Gabrielli E, Amacker M, Kasper L, Roselletti E, et al. (2015) Secretary aspartyl proteinases cause vaginitis and can mediate vaginitis caused by Candida albicans in mice. MBio 6(3): e00724.

20. Bernardis F, Amacker M, Arancia S, Sandini S, Gremion C, et al. (2012) A virosomal vaccine against candidial vaginitis: immunogenicity, efficacy and safety profile in animal models. Vaccine 30(30): 4490-4498.

21. Segal $E$ (2017) Testing antifungal vaccines in an animal model of invasive candidiasis and in human mucosal candidiasis. Methods Mol Biol 1625: 343-353. 
Creative Commons Attribution 4.0

International License

For possible submissions Click Here

Submit Article

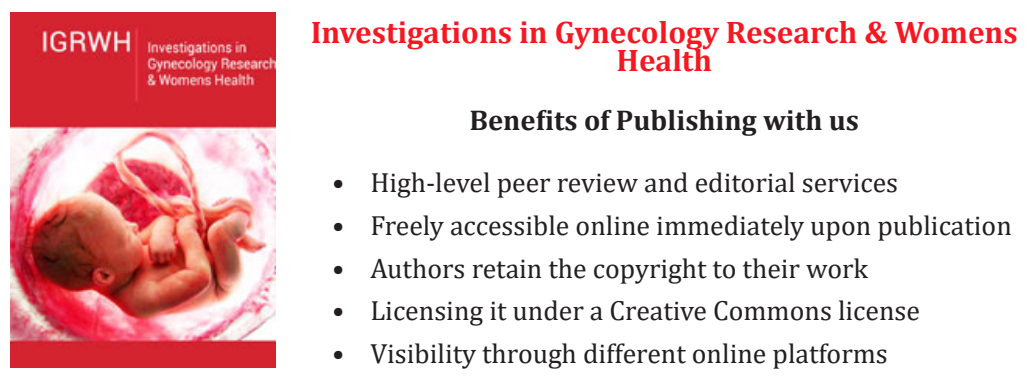

